\title{
GUETTARDA SIERRAE (RUBIACEAE), A NEW SPECIES FROM THE NE COAST OF CUBA AND LECTOTYPIFICATION OF GUETTARDA UNDULATA
}

\author{
P. A. GonzÁlez G. ${ }^{1}$ and J. L. Gómez H. ${ }^{2}$ \\ ${ }^{1}$ Centro de Investigaciones y Servicios Ambientales y Tecnológicos de Holguín (CISAT) \\ CITMA, Calle 18 sn, entre 1a y Maceo, Reparto "El Llano", Holguín 80 100, Cuba \\ E-mail:pagg@cisat.cu,pagg74@yahoo.es \\ ${ }^{2} J a r d i ́ n$ Botánico de Holguín, Carretera al Valle de Mayabe km 5 1/2, Holguín 80 100, Cuba \\ E-mail: jluis@cisat.cu; jlgomez87@nauta.cu
}

(Received: 13 May, 2019; Accepted: 5 August, 2019)

Guettarda sierrae, a new species from the NE coastal fringe of Cuba, is described and compared with other species of the genus occurring in Cuba. Aspects of its distribution and conservation status are discussed. A lectotype for Guettarda undulata, a Cuban species related to Guettarda sierrae, is proposed herein.

Key words: conservation, endemism, flora of Holguín, Guettarda camagueyensis, G. clarensis, G. cueroensis, G. rigida, G. undulata, taxonomy

\section{INTRODUCTION}

Guettarda L. (Rubiaceae) comprises ca 100 species distributed in the Neotropics, most of them in The West Indies (Borhidi et al. 2017). Britton (1915) recorded 26 species, seven of them described by him, for the Cuban archipelago, and in the treatment of Alain (1964) the number increased to 32. Greuter and Rankin (2017) listed 36 species occurring in Cuba, of which 30 are endemics, whereas Borhidi et al. (2017) cited 34 species and a variety to Cuba, of which 29 are endemic.

The locality of Caletica, in the municipality of Rafael Freyre, province of Holguín in NE Cuba, was visited in November of 2001 with the main goal to make a checklist of the flora. A small leaved Guettarda with 1-flowered inflorescences was found in the coastal xeromorphic thicket and having found affinities among it and the description of Guettarda rigida A. Rich. appearing in the fifth volume of Flora of Cuba (Alain 1964), and it was identified as Guettarda cf. rigida (González G. et al. 2004-2005). Some years later the species was also found in two other localities of the Holguín's coastal fringe. In that time we could access to the reference collections of the Cuban herbaria HAC and HAJB and realised that the Guettarda found in the coast of Holguín did not match with Guettarda rigida, but most probably with Guettarda undu- 
lata Griseb., and for this reason the species was then identified as Guettarda aff. undulata (González G. 2015, González G. et al. 2015, 2017). Such affinity was corroborated once observed the images of the type of Guettarda undulata (which was sent us by M. Appelhans), the specimen Rugel 628 (GOET\#10342) collected "In rupibus supra Punta Brava prope Matanzas, Ins. Cuba 1849" (See discussion about typification of G. undulata below). During the preparation of this manuscript we also observed images of the specimens Rugel 628 (NY\#115133) and Ekman 17214 (NY\#1325955), collected in August 1923 near Matanzas city, which were the only other known specimens of this species apart from the type until the species has been recently found by botanists of Matanzas. Thanks to a courtesy of Lenia Robledo, botanist of Botanical Garden of Matanzas, we received photos of the plants relocated in Matanzas, in western Cuba, about $600 \mathrm{~km}$ far from Holguín, and observed that although they have morphological affinities they differ from the plants in Holguín by having leaves with apex mostly obtuse or rounded, and fruits with surface rough and greenish tomentulose, whereas the plants from Holguín have leaves with apex acute, slightly acuminate, frequently mucronate and fruits without pubescence or little puberulous. We also checked the descriptions and the type specimens of other Cuban Guettarda with small leaves and 1-flowered inflorescences such as Guettarda camagueyensis Britton, G. clarensis Britton, G. cueroensis Britton and G. rigida A. Rich. (see discussion of morphological characters below), and noticed that the plants of the coastal fringe of Holguín differ from them mainly in the characteristics of the leaves and of the fruit and for this reason this taxon is here described as a new species.

\section{Guettarda sierrae P. A. González et J. L. Gómez, spec. nova} (Figs 1-2)

Morphological diagnosis: Leaf blade narrow ovate, $0.9-3.5 \times 0.4-1.5 \mathrm{~cm}, \mathrm{co}-$ riaceous, base slightly cordate or rounded, margin minutely crenulated and slightly recurved, adaxially with scattered small hairs, glabrescent, apex acute, slightly acuminate, frequently mucronulate. Inflorescence sessile or borne on a ca $3 \mathrm{~mm}$ stalk, 1(-3)-flowered. Flower 5-6-mera, heterostylous. Fruit globose, ca $1 \mathrm{~cm}$ in diam., sometimes with persistent calyx, green (unripe) turning creamish orange or pale orange (when ripe); pyrenes 5-7 × 4-5 $\mathrm{mm}$.

Type: Cuba, province of Holguín, municipality of Gibara, cerca de $2 \mathrm{~km}$ al Oeste del parque eólico Gibara 1, 2-3 km al Sur de la carretera GibaraCaletones, matorrales xeromorfos sobre carso, coll.: P. A. González Gutiérrez (HFC\#88169), 1 Nov 2013 (fruits), (holotype: HAJB\#1136; isotype: herbarium of Botanical Garden of Holguín [whithout acronym]) [HFC = series of the Herbarium of the Flora of Cuba]. 
Morphological description: Shrubs up to 2-3 m high, densely branched. Trunk up to $\mathrm{ca} 15 \mathrm{~cm}$ in diameter, greyish. Stipules $3 \times 2 \mathrm{~mm}$, dorsally pubescent with apex acute; petiole 1-2 mm long, ca $1.5 \mathrm{~mm}$ thick, densely pubescent; leaf blade adaxially dark green, abaxially paler green, narrow ovate, $0.9-3.5 \times 0.4-1.5 \mathrm{~cm}$, coriaceous, adaxially with scattered hairs ( $<1 \mathrm{~mm}$ long), glabrescent, base slightly cordate or rounded, margin minutely crenulated and slightly recurved, apex acute, slightly acuminate, frequently mucronulate; midvein and secondary veins prominent abaxially, tertiary veins strong reticulate abaxially (Fig. 2B); secondary veins 5-7 pairs forming an angle of $45-60^{\circ}$ with the midvein. Inflorescence sessile or borne on a $c a 3 \mathrm{~mm}$ pubescent stalk, 1(-3)-flowered (Fig. 2A, B), bracts rarely present only in 3-flowered cymes, $5-7 \times 0.5 \mathrm{~mm}$, pubescent. Flower heterostylous, $12-15 \mathrm{~mm}$ in diam., tube 15-20 mm long, pubescent; calyx 4-5 mm long, white greenish turning pale pink, pubescent; petals $5-6$, white, ca $5 \mathrm{~mm}$ long with apex rounded (Fig. $2 \mathrm{~A})$; anthers attached to the upper part of the corolla tube, $1.7-2 \times 0.2-0.3 \mathrm{~mm}$; styles 5-22 $\mathrm{mm}$ long, pale green, stigma with shape of club, green (Fig. 2C). Fruit globose, ca $1 \mathrm{~cm}$ in diam., sometimes with persistent calyx, green (unripe) turning creamish orange or pale orange (when ripe), glabrous until little

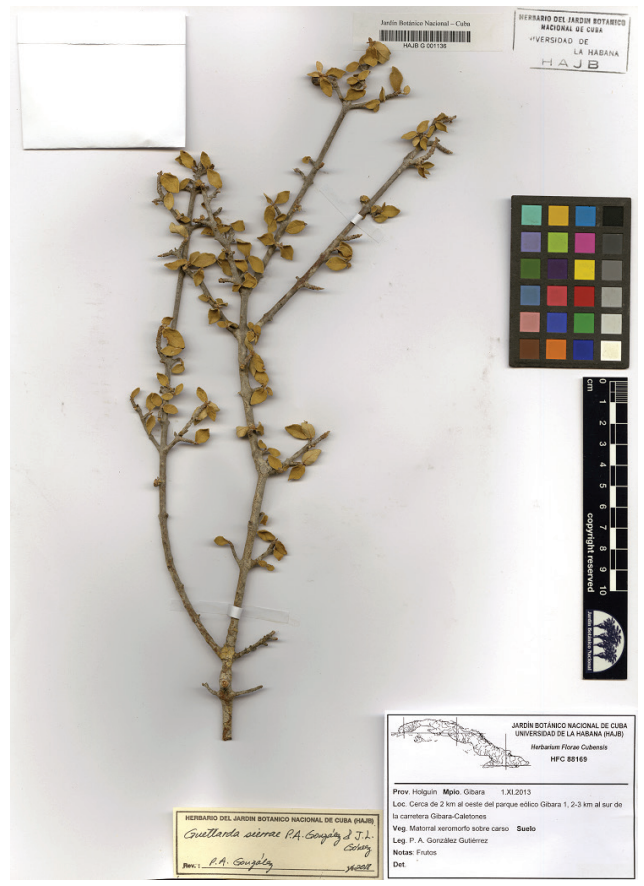

Fig. 1. Holotype of Guettarda sierrae, deposited in the Herbarium of the National Botanical Garden of Cuba (HAJB) puberulous (unripe) (Fig. 2D); pyrenes 5-7 × 4-5 mm.

Etymology: The specific epithet honours Jorge Sierra Calzado (1956-1999), eminent professor of Botany of Universidad de Oriente, Santiago de Cuba, who made important contributions to the knowledge of the Flora of Cuba (Leiva S. 2000).

Phenology: The species has been collected in flower in April and September and in fruit in October, November and December.

Ecology: The species has been collected in xeromorphic coastal thickets with other species of shrubs such as: Bonania cubana A. Rich., Capparis ferruginea subsp. cubensis R. Rankin, Chascotheca neopeltandra (Griseb.) Urb., Erithalis fruticosa L., Flueggea acidoton (L.) G. L. Webster, Gymnanthes lucida Sw., Lasiocroton microphyllus (A. Rich.) 

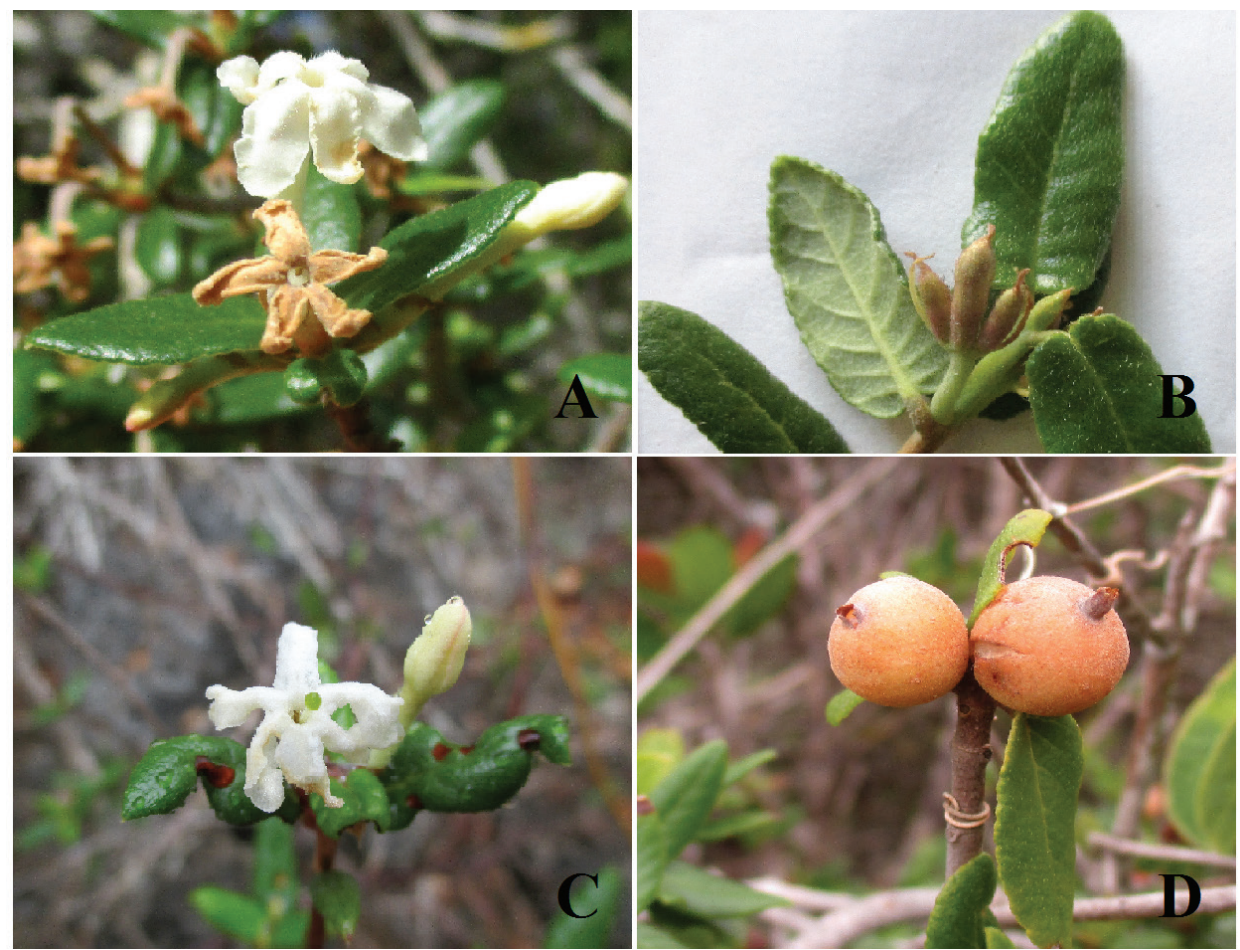

Fig. 2. Guettarda sierrae - A = flowering branch (Rafael Freyre: Caletica); $\mathrm{B}=$ an uncommon 3-flowered cyme (Rafael Freyre: Caletica); C = longistylous flower (Gibara: Los Cocos); D = fruiting branch (Banes: Cabo Lucrecia) (photos A-D by Pedro Alejandro González Gutiérrez)

Jestrow, Maytenus buxifolia (A. Rich.) Griseb., Oplonia polyece (Stearn) Borhidi and Rochefortia stellata Britton et P. Wilson.

Distribution: Guettarda sierrae is a local endemic of the coastal fringe of the province of Holguín in NE Cuba. It has been collected in the municipalities of Gibara, Rafael Freyre and Banes (Fig. 3).

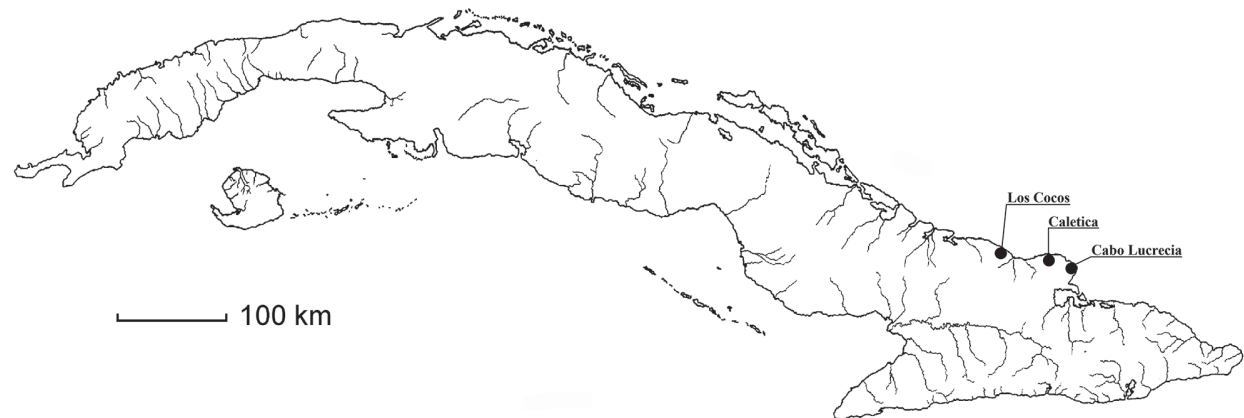

Fig. 3. Localities where Guettarda sierrae was collected on NE coast of Cuba 
Conservation status: In the last 15 years three populations of Guettarda sierrae have been found in Los Cocos (municipality of Gibara), Caletica (municipality of Rafael Freyre) and Cabo Lucrecia (municipality of Banes). These three localities are separated by ca $40 \mathrm{~km}$ (Los Cocos and Caletica) and by ca $30 \mathrm{~km}$ (Caletica and Cabo Lucrecia). Other coastal areas of NE Cuba have been explored in the last 15 years, but no other populations of G. sierrae were found. The estimate of the area of occupancy of this species is less than 10 $\mathrm{km}^{2}$. The population of Caletica comprises less than five plants and are near a touristic area, and the population of Cabo Lucrecia is included in the protected area Floristic Reserve of Cabo Lucrecia. The habitat of this new species has been severely fragmented by agricultural, forestry and touristic activity in the last 10 years and we estimated that this tendency would continue in the future. Thus, according to IUCN criteria (IUCN 2012), G. sierrae must be classified as critically endangered: CR: B2ab(ii,iii,v).

Taxonomic remarks: The most outstanding character of Guettarda sierrae are its small leaves and the 1(-3)-flowered cymes, which makes it morphologically related to the first nine species listed by Alain (1964), mostly to those
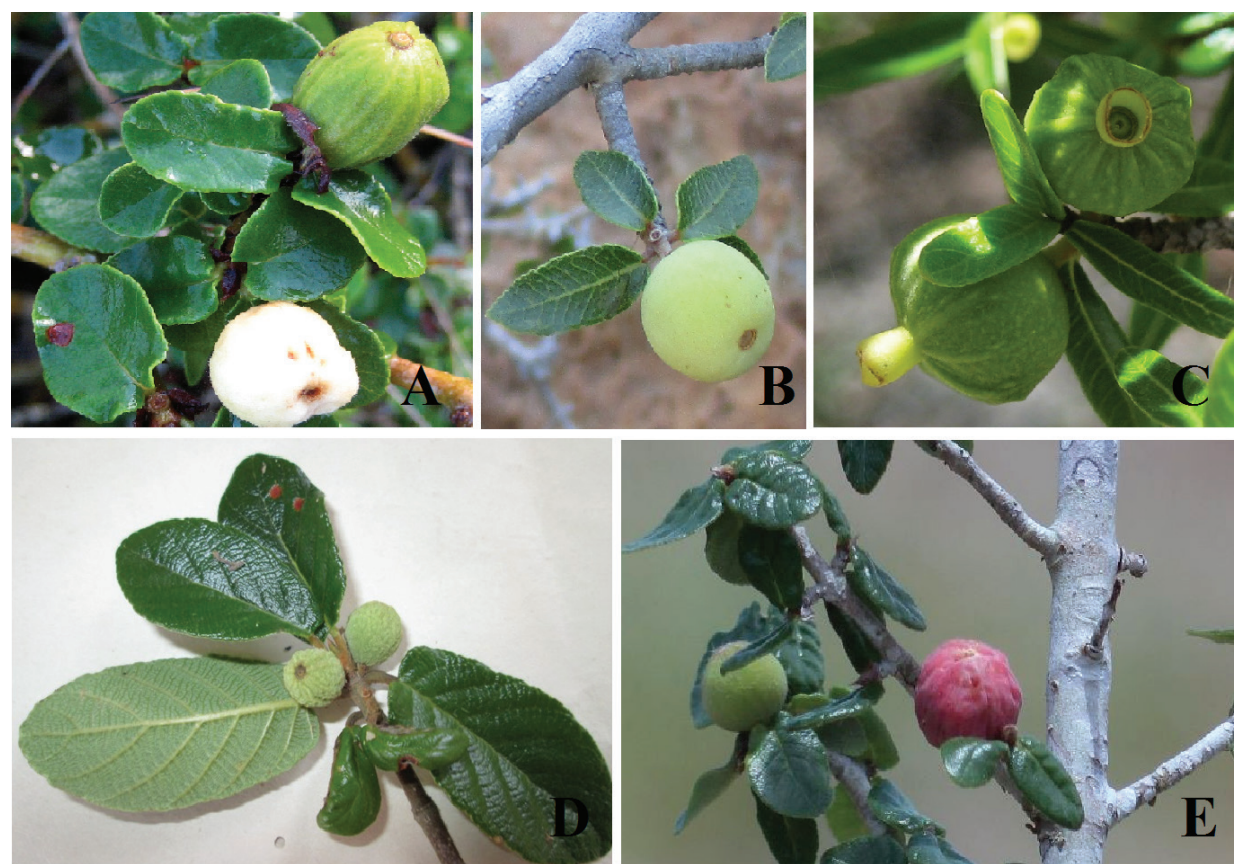

Fig. 4. Fruiting branches of other species of Cuban Guettarda morphologically related to G. sierrae. $-\mathrm{A}=$ Guettarda camagueyensis; $\mathrm{B}=$ G. cueroensis $; \mathrm{C}=\mathrm{G}$. rigida; $\mathrm{D}=\mathrm{G}$. undulata; $\mathrm{E}$ = G. clarensis (photos: A-C by Pedro Alejandro González Gutiérrez; D courtesy of Ricardo Cruz Nardo, Lenia Robledo Ortega and Amalia Enríquez Rodríguez; E by Arnaldo Toledo Sotolongo) 
with base chordate to subchordate: Guettarda camagueyensis, G. clarensis, G. cueroensis, G. rigida and G. undulata. The most outstanding differences among these species are in the shape, colour and hairs of the fruit. Guettarda camagueyensis differs from G. sierrae by its leaves wider, fruit with longitudinal ribs turning white when ripe (Fig. 4A); Guettarda clarensis and G. cueroensis differ from G. sierrae by their tomentulose fruits (Fig. 4B), which turns pale purple when ripe in the case of G. clarensis (Fig. 4E); Guettarda rigida has a fruit pyriform-globose, more less angulose due to longitudinal ribs (Fig. 4C) and Guettarda undulata has fruit greenish tomentulose (Fig. 4D), whereas Guettarda sierrae glabrous or almost glabrous, green (unripe) turning creamish orange or pale orange when ripe (Fig. 2D). These species grow in distant geographical areas of Cuba, and some of them in different ecological ecosystems. Guettarda camagueyensis grows in the serpentine outcrop of Camagüey (phytogeographical district Camagüeyense). Guettarda clarensis grows in the serpentine outcrop of Santa Clara (Phytogeographical district Clarense), Guettarda cueroensis grows in Cuba and also in Hispaniola; in Cuba it grows in the coastal xeromorphic thickets of southeastern Cuba between Cabo Cruz (province Granma) and Maisí (Guantánamo), including localities of province Santiago de Cuba in the Phytogeographical districts Pilonense, Uveroense and Guantanamense. Guettarda rigida is widespread in dry ecosystems on limestone and serpentine in several localities of eastern, central and western Cuba and Guettarda undulata is strict endemic of coastal xeromorphic thickets of Matanzas; whereas Guettarda sierrae is strict endemic of the xeromorphic coastal thickets on limestone between Los Cocos (Gibara) and Cabo Lucrecia (Banes) in the Phytogeographical district Gibarense. For more information about the Phytogeography of Cuba see Borhidi (1991).

Additional specimens seen: CUBA: Province of Holguín: Municipality of Banes, Cabo Lucrecia, matorral xeromorfo costero, 16-19 Dic 2014 (fruits), P. A. González Gutiérrez HFC 88270 (HAJB); Municipality of Gibara, Los Cocos, matorral xeromorfo costero, 21 Abr 2017 (flowers), P. A. González Gutiérrez 1404-14 (HAJB); Municipality of Rafael Freyre, Caletica, 24 Oct 2013 (fruits), P. A. González Gutiérrez HFC 88156 (HAJB), Rafael Freyre, Caletica, matorral xeromofo costero, N 21 07' 02,9"'; W 75 51' 40,4", 14 Sept 2018, P. A. González Gutiérrez 1809-5 (B, HAJB, HAC, PAL-Gr, Herbarium of Holguín Botanical Garden).

Typification of Guettarda undulata: The other specimen mentioned by Grisebach (1866) in the protologue of Guettarda undulata, Wright 2705 (=196) [GOET\#10343], collected in eastern Cuba, belongs to Guettarda cueroensis, although R. A. Howard had proposed it as the lectotype in 21 June 1984. This means that the lectotype of Guettarda undulata should be the specimen Rugel 628, collected in Matanzas and deposited at GOET. 
Acknowledgements - We are grateful to project "Estudios taxonómicos en plantas vasculares cubanas" of "Programa Nacional de Biodiversidad", which has allowed the exploration of the coastal fringe of Holguín, including the areas where Guettarda sierrae grows. We thank Marc Appelhans, curator of herbarium GOET (Germany), for sending us the images of the type specimen of G. undulata, to Lenia Robledo Ortega (Botanical Garden of Matanzas, Cuba), who sent us images of fresh leaves and fruits of G. undulata, to Eddy Martínez Quesada from CIMAC (Camagüey, Cuba) for supporting the first author during field trip in Camagüey, that allowed to see and make images of G. camagueyensis and to Arnaldo Toledo Sotolongo, Idelfonso Castañeda Noas and Alfredo Noa Monzón (University of Santa Clara, Cuba) for sharing with us images and information about G. clarensis.

\section{REFERENCES}

Alain [Liogier A. H.] (1964): Flora de Cuba, 5. Rubiales, Valerianales, Cucurbitales, Campanulales, Asterales. - Asoc. Est. Cienc. Biol. Publ. La Habana.

Borhidi, A. (1991): Phytogeography and vegetation ecology of Cuba. - Akadémiai Kiadó, Budapest.

Borhidi, A., Fernández-Zequeira, M. and Oviedo-Prieto, R. (2017): Rubiáceas de Cuba. Akadémiai Kiadó, Budapest.

Britton, N. L. (1915): Studies of West Indian plants VII. - Bull. Torrey Bot. Club 42: 487-517.

González G., P. A. (2015): Reporte de exploraciones botánicas recientes en localidades de Gibara, provincia de Holguín, Cuba. - Rev. Jard. Bot. Nac. 36: 103-111.

González G., P. A., Suárez T., S. I., Sigarreta V., S., Fernández V., A. and Laffita G., O. (2004-2005): Flora y vegetación de Caletica, Rafael Freyre, Holguín. - Rev. Jard. Bot. Nac. 25-26: 131-140.

González G., P. A., Gómez H., J. L., Leyva B., O. and Hernández, Y. (2015): Flora de la Reserva Florística Manejada Cabo Lucrecia-Punta de Mulas, Banes, Holguín. - Rev. Jard. Bot. Nac. 36: 65-77.

González G., P. A., Suárez T., S. I., Leyva B., O., Gómez H., J. L. and Carmenate R., W. (2017): Flora y vegetación de la Reserva Ecológica Caletones, Gibara, Holguín, Cuba. - Rev. Jard. Bot. Nac. 38: 15-41.

Greuter, W. and Rankin, R. (2017): Plantas vasculares de Cuba: inventario preliminar. Segunda edición, actualizada, de Espermatófitos de Cuba con inclusión de los Pteridófitos. Vascular plants of Cuba: a preliminary checklist. Second updated edition of The Spermatophyta of Cuba with Pteridophyta added. - Berlin: Botanischer Garten \& Botanisches Museum Berlin; La Habana: Jardín Botánico Nacional, Universidad de La Habana. https://doi.org/10.3372/ cubalist.2017.1

Grisebach, A. (1866): Catalogus Plantarum Cubensium exhibens collectionem Wrightianam aliasque minores ex insula Cuba missas. - Lipsiae [Leipzig].

IUCN (2012): IUCN Red List categories and criteria. Version 3.1, ed. 2. - IUCN, Gland \& Cambridge.

Leiva S., A. T. (2000): Falleció el Dr. Jorge Sierra Calzado. - Rev. Jard. Bot. Nac. 21(2): 161. 